Provided for non-commercial research and educational use only. Not for reproduction or distribution or commercial use.

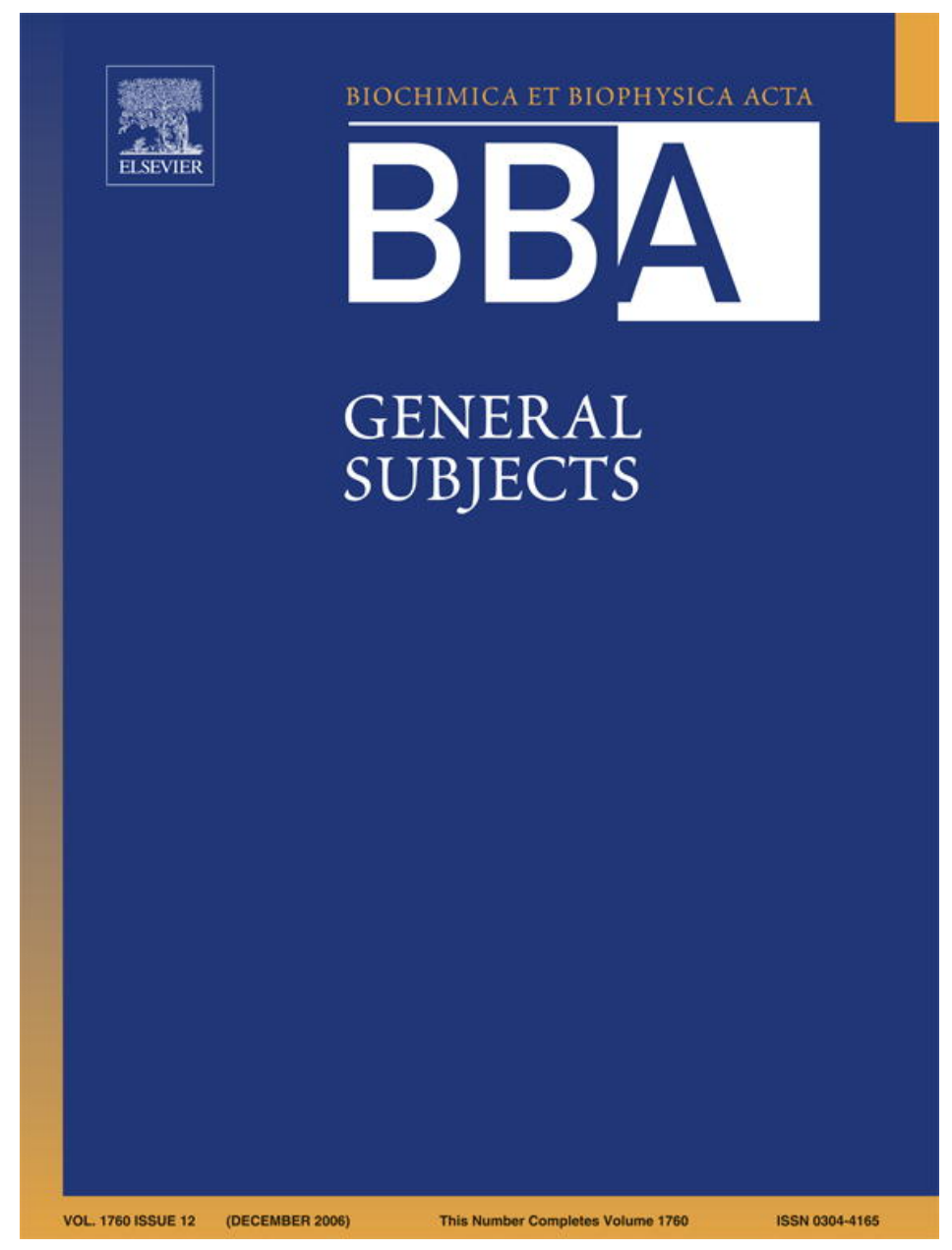

This article was originally published in a journal published by Elsevier, and the attached copy is provided by Elsevier for the author's benefit and for the benefit of the author's institution, for non-commercial research and educational use including without limitation use in instruction at your institution, sending it to specific colleagues that you know, and providing a copy to your institution's administrator.

All other uses, reproduction and distribution, including without limitation commercial reprints, selling or licensing copies or access,

or posting on open internet sites, your personal or institution's website or repository, are prohibited. For exceptions, permission may be sought for such use through Elsevier's permissions site at: 


\title{
Down-regulation of $\mathrm{ABCB} 1$ transporter by atorvastatin in a human hepatoma cell line and in human peripheral blood mononuclear cells
}

\author{
Alice Cristina Rodrigues ${ }^{\mathrm{a}, *}$, Rui Curi ${ }^{\mathrm{b}}$, Luiz R.G. Britto ${ }^{\mathrm{b}}$, Ivanise M.M. Rebbechi ${ }^{\mathrm{a}}$, \\ Mario H. Hirata ${ }^{\text {a }}$, Marcelo C. Bertolami ${ }^{\text {, }}$, Marcia M.S. Bernik ${ }^{d}$, \\ Egidio L. Dorea ${ }^{\mathrm{d}}$, Rosario D.C. Hirata ${ }^{\mathrm{a}}$

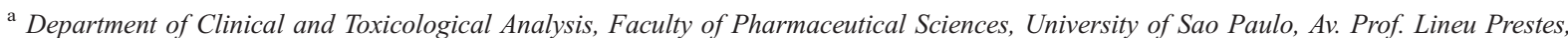 \\ 580, Sao Paulo, SP, 05508-900, Brazil \\ ${ }^{\mathrm{b}}$ Department of Physiology and Biophysics, Institute of Biomedical Sciences, University of Sao Paulo, Av. Prof. Lineu Prestes, 1524 \\ Sao Paulo, SP, 05508-900, Brazil \\ ${ }^{c}$ Dante Pazzanese Institute of Cardiology, Sao Paulo, SP, 04012-180, Brazil \\ ${ }^{\mathrm{d}}$ Hospital Universitário, University of Sao Paulo, Sao Paulo, SP, 05508-900, Brazil
}

Received 13 February 2006; received in revised form 25 July 2006; accepted 1 August 2006 Available online 8 August 2006

\begin{abstract}
Purpose. The effect of atorvastatin, an HMG-CoA reductase inhibitor, on expression and activity of the drug transporter ABCB1 in HepG2 cells and peripheral blood mononuclear cells (PBMCs) was examined. Methods. Localization and expression of ABCB1 in hepatocytes was examined by indirect immunofluorescence. Expression of $A B C B 1$ mRNA and $\mathrm{ABCB} 1$ activity were examined in atorvastatin-treated and control cells and PBMCs using real-time PCR and Rhodamine 123 efflux assay. Results. Immunohistochemical analysis revealed that ABCB1 is located at the apical membrane of the bile canaliculi. Atorvastatin at 10 and $20 \mu \mathrm{M}$ up-regulated ABCB1 expression resulting in a significant 1.4-fold increase of the protein levels. Treatment of HepG2 cells with $20 \mu \mathrm{M}$ atorvastatin caused a $60 \%$ reduction on mRNA expression $(p<0.05)$ and a $41 \%$ decrease in ABCB1-mediated efflux of Rhodamine123 $(p<0.01)$ by flow cytometry. Correlation was found between $A B C B 1$ mRNA levels and creatine kinase $(r=0.30 ; p=0.014)$ and total cholesterol $(r=-0.31 ; p=0.010)$. Conclusions. Atorvastatin leads to decreased ABCB1 function and modulates ABCB1 synthesis in HepG2 cells and in PBMCs. ABCB1 plays a role in cellular protection as well as in secretion and/or disposition, therefore, inhibition of $\mathrm{ABCB} 1$ synthesis may increase the atorvastatin efficacy, leading to a more pronounced reduction of plasma cholesterol.
\end{abstract}

(C) 2006 Elsevier B.V. All rights reserved.

Keywords: ABCB1; Atorvastatin; HepG2; ABCB1 mRNA; PBMC

\section{Introduction}

Inhibitors of the 3-hydroxy-3-methylglutaryl coenzyme A (HMG-CoA) reductase, also known as statins, are therapeutic agents used for the treatment of hypercholesterolemia [1]. Statins inhibit the synthesis of cholesterol by suppressing the conversion of HMG-CoA into mevalonate and up-regulate the low-density lipoprotein (LDL) receptor gene. Mevalonate is the

\footnotetext{
* Corresponding author. Faculdade de Ciências Farmacêuticas, Universidade de São Paulo, Av. Prof. Lineu Prestes, 580, B17, 05508-900 São Paulo, SP, Brasil. Fax: +55 1138132197.

E-mail address: alice-rodrigues@uol.com.br (A.C. Rodrigues).
}

precursor not only of cholesterol but also of many nonsteroidal isoprenoid compounds that are involved in cell signaling, cell differentiation, and proliferation [2]. Statins also present pleiotropic effects such as anti-inflammatory and anti-proliferative actions.

Atorvastatin is an HMG-CoA reductase inhibitor with high therapeutic efficacy due to its elevated plasma elimination half-life $\left(t_{1 / 2}\right)$ of $14 \mathrm{~h}$ [3]. However, some patients do not respond to atorvastatin treatment or to other statins [4], whereas others present important adverse effects [5]. The interindividual differences in response to statins have been related to several factors that affect drug distribution and pharmacokinetics. 
Specific membrane transporters have a significant impact on the overall drug disposition process through their targeted expression in organs such as intestine, kidney and liver [6]. The compartmentalized expression of certain transporters in various tissues plays a critical role in drug disposition. In the liver, several transporters are involved in uptake and efflux of exogenous (drugs) and endogenous substrates from the bloodstream. Drugs may undergo further biotransformation and can be excreted unmodified into bile for subsequent elimination from the body.

ATP-binding cassette sub-family B member 1 (ABCB1), previously named multidrug resistance transporter 1 (MDR1), is an efflux transporter, which uses energy derived from ATP hydrolysis to translocate substrates across biological membranes. ABCB1 transports a wide range of structurally diverse drugs such as atorvastatin, cyclosporine, indinavir, and fexofenadine (reviewed in [7]). ABCB1 has been shown to be a particularly important efflux transporter that can extrude or pump drugs back into the intestinal lumen, effectively limiting their bioavailability.

Atorvastatin has been identified as an $\mathrm{ABCB} 1$ substrate in vitro $[8,9]$. In the liver, the statins undergo metabolism that is mediated by phase I and II enzymes, or may be excreted unchanged. ABCB1, located at canalicular membrane of hepatocytes, contributes for elimination of statins and their metabolites via bile [1]. Translocation of drugs across epithelial cells may be hindered or facilitated by the localization of transporters on apical or basolateral membranes. Thus, the mechanisms involved in transporter-mediated drug disposition represent an important issue to be investigated.

Single nucleotide polymorphisms in $A B C B 1$ gene may play a role in the disposition of many drugs. C3435T polymorphism was found to be associated with variation in intestinal $\mathrm{ABCB} 1$ levels that regulate the uptake of orally administered ABCB1 substrates such as digoxin [10], fexofenadine [11] and cyclosporine [12]. Subjects carrying the 3435TT genotype have remarkably lower duodenal $\mathrm{ABCB} 1$ expression and higher plasma digoxin levels in comparison to individuals with $\mathrm{CC}$ or $\mathrm{CT}$ genotypes $[10,13,14]$. The C3435T and G2677T/A polymorphisms were associated with drug responses in patients treated with atorvastatin [15], nelfinavir [16], digoxin [10], and tacrolimus [17]. Rodrigues et al. [18] did not find a significant effect of these polymorphisms on the response to atorvastatin in hypercholesterolemic patients. However, haplotype analysis revealed that european-derived brazilians carrying the $\mathrm{T} / \mathrm{T}$ haplotype have high levels of total and LDL cholesterol compared with non-T/T carriers.

In the present study the expression of mRNA of $A B C B 1$ gene was investigated in human peripheral blood mononuclear cells and its association with $\mathrm{C} 3435 \mathrm{~T}$ polymorphism in the ABCB1 gene. We also studied the effects of atorvastatin on the expression and activity of the drug transporter ABCB1 in HepG2 cells, which represent a hepatocyte model for studies of liver-specific cellular functions and highly express HMG-CoA reductase that is the target of statins.

\section{Materials and methods}

\subsection{Chemicals}

Atorvastatin was kindly provided by Pfizer Pharmaceuticals Ltd. (Guarulhos, SP, Brazil). Dulbecco's modified Eagle medium (DMEM), penicillin, TRIzol ${ }^{\circledR}$ reagent ${ }^{\mathrm{TM}}$ and streptomycin were purchased from Invitrogen (Carlsbad, CA, USA). Trypsin-versene mixture containing trypsin $(0.2 \%)$ and versene $(0.02 \%)$ was obtained from Adolfo Lutz Institute (Sao Paulo, SP, Brazil). Verapamil hydrochloride $( \pm)$, goat anti-mouse IgG FITC conjugated, Triton-X-100, Histopaque-1077, glutamine and mevalonic acid lactone were purchased from Sigma (St. Louis, MO, USA). Anti-human P-glycoprotein monoclonal antibody 17F9 was obtained from Pharmingen-BD Biosciences (San Diego, CA, USA). Propidium iodide was obtained from ICN Biomedicals (Costa Mesa, CA, USA). Citrate was purchased from Merck (Frankfurter, Darmstadt, Germany) and sodium bicarbonate from Labsynth products (Diadema, SP, Brazil). Rhodamine 123 (Rh123) was obtained from Molecular Probes (Eugene, OR, USA). Human hepatocellular carcinoma cell line HepG2 was obtained from the Cell Bank of Rio de Janeiro (Rio de Janeiro, RJ, Brazil). Revertaid ${ }^{\mathrm{TM}}$ M-MuLV Reverse Transcriptase was purchased from MBI Fermentas (Burlington, Ontario, Canada). Primers and probes for TaqMan ${ }^{\circledR}$ real-time PCR were purchased from Applied Biosystem (Foster City, CA, USA). DNA polymerase was purchased from Biotools (Madrid, Spain).

\subsection{Subjects and blood samples}

The characteristics of the study design [18] have been previously reported. Briefly, subjects with primary hypercholesterolemia were admitted to the Dante Pazzanese Institute of Cardiology (São Paulo, SP, Brazil) and to the Hospital Universitário of University of Sao Paulo (São Paulo, SP, Brazil) and individuals that remained with Low Density Lipoprotein (LDL) cholesterol higher than $160 \mathrm{mg} /$ day, even after a low cholesterol diet, were started on atorvastatin therapy, $10 \mathrm{mg}$ orally once daily for 4 weeks. Identical protocols were reviewed and approved by the institutional review board at each research center, and written informed consent was obtained from each patient before inclusion in the study. Sixty-nine individuals ( 28 men, 41 women, mean age: 58 years) with $L D L$ cholesterol (mean \pm S.D.: $197 \pm 37 \mathrm{mg} / \mathrm{dL}$ ) were studied. Blood samples for lipid and lipoprotein measurements, creatine kinase and alanine transferase, isolation of peripheral blood mononuclear cells (PBMCs) and for DNA isolation were collected after an overnight fast, before and after atorvastatin administration.

\subsection{Isolation of PBMCs}

Peripheral blood mononuclear cells were obtained as previously described [19]. Blood was diluted in phosphate-buffered saline (PBS) $(1: 1)$ and this suspension was layered on Histopaque-1077 and centrifuged for $30 \mathrm{~min}$ at $400 \times g$ and room temperature. Peripheral blood mononuclear cells (PBMC; a mixture of monocytes and lymphocytes) were collected from the interphase.

\subsection{ABCB1 genotyping}

Genomic DNA was extracted from EDTA-anticoagulated blood by a saltingout procedure. $\mathrm{C} 3435 \mathrm{~T}$ ABCB1 polymorphism in exon 26 was genotyped by PCR-restriction fragment length polymorphism (RFLP) according to Rodrigues et al. [18]. C3435T $A B C B 1$ polymorphic regions were amplified by the polymerase chain reaction (PCR). PCR assays were performed with $50 \mathrm{ng}$ genomic DNA, amplification buffer $\left(50 \mathrm{mM} \mathrm{KCl}, 20 \mathrm{mM}\left(\mathrm{NH}_{4}\right)_{2} \mathrm{SO}_{4}, 2 \mathrm{mM}\right.$ $\mathrm{MgCl}_{2}, 75 \mathrm{mM}$ Tris- $\mathrm{HCl}, \mathrm{pH} 9.0$ ), $200 \mu \mathrm{M}$ primers, and $0.5 \mathrm{U}$ DNA polymerase. The primers used for PCR were as follows: forward $5^{\prime}$ TCCTTAATCTCACAGTAACTTGGCA-3' and reverse 5'-AGGCCAACATACATGCCTTCAT- $3^{\prime}$. The thermal cycler protocol consisted of initial denaturation at $98^{\circ} \mathrm{C}$ for 3 min followed by 35 cycles of denaturation at $94{ }^{\circ} \mathrm{C}$ for $1 \mathrm{~min}$, annealing at $60^{\circ} \mathrm{C}$ for $2 \mathrm{~min}$ and extension at $72{ }^{\circ} \mathrm{C}$ for $2 \mathrm{~min}$. Amplification was carried out in a thermal cycler, PTC-200 (MJ Research Inc., Walthan, MA, USA). PCR products were analyzed by $1.5 \%$ agarose gel electrophoresis after ethidium bromide staining. 
C3435T polymorphisms were detected by digestion of PCR-amplified products using the restriction enzymes MboI. Enzymatic digestions were performed at $37^{\circ} \mathrm{C}$ for $1 \mathrm{~h}$ in a total volume of $10 \mu \mathrm{l}$ using $1 \mathrm{U}$ restriction endonuclease and $1 \times$ restriction buffer $(33 \mathrm{mM}$ Tris-acetate, $10 \mathrm{mM}$ magnesium acetate, $66 \mathrm{mM}$ potassium acetate, $0.1 \mathrm{mg} / \mathrm{ml} \mathrm{BSA}, \mathrm{pH}$ 7.9). Restriction fragments were identified by $8 \%$ polyacrylamide gel electrophoresis after silver staining.

\subsection{Cell culture}

HepG2 cells were maintained in DMEM supplemented with $10 \%$ fetal bovine serum, $2 \mathrm{mM}$ glutamine, $44 \mathrm{mM}$ sodium bicarbonate, 10,000 UI/mL streptomycin and $10,000 \mathrm{UI} / \mathrm{mL}$ penicillin. Cells were grown at $37{ }^{\circ} \mathrm{C}$ in a humidified atmosphere, containing $5 \% \mathrm{CO}_{2}$. Culture medium was replaced twice a week and cells were trypsinized and subcultured every 7 days.

\subsection{Atorvastatin treatment}

Atorvastatin was dissolved in methanol. The final concentration of methanol in the culture medium did not exceed $0.1 \%$. Preliminary experiments with this concentration of methanol did not show cytotoxicity. Four concentrations of atorvastatin were tested, starting from vehicle control $(0 \mu \mathrm{M})$ and $0.1 \mu \mathrm{M}$ as the lowest concentration up to a maximum of $20 \mu \mathrm{M}$. The cells were treated with atorvastatin at various concentrations for $24 \mathrm{~h}$.

\subsection{Cell viability}

The percentage of viable HepG2 cells treated with atorvastatin was determined by flow cytometry using propidium iodide solution $(50 \mathrm{mg} / \mathrm{mL}$ in phosphate buffer saline) to detect membrane integrity of the cells. Propidium iodide is a highly water-soluble fluorescent compound that cannot pass through intact membranes and being generally excluded from viable cells. It binds to DNA by intercalating between the bases with little or no sequence preference.

\subsection{DNA fragmentation}

DNA fragmentation was analyzed by flow cytometry after DNA staining with propidium iodide according to the method previously described by Nicoletti et al. [20]. Briefly, cells $\left(5 \times 10^{5}\right)$ were gently resuspended in $200 \mu \mathrm{L}$ hypotonic solution containing $50 \mu \mathrm{g} / \mathrm{mL}$ propidium iodide, $0.1 \%$ sodium citrate, and $0.1 \%$ Triton $\mathrm{X}-100$. The cells were then incubated overnight at $4{ }^{\circ} \mathrm{C}$. Fluorescence was measured and analyzed by flow cytometry.

\subsection{Immunohistochemical detection of $A B C B \quad 1$}

HepG2 cells were grown on glass cover slips and processed for immunofluorescence microscopy. Cell layers were washed with phosphate buffer saline (PBS), $\mathrm{pH} 7.4$, and fixed in $2 \%(\mathrm{v} / \mathrm{v}) p$-formaldehyde solution for $5 \mathrm{~min}$ at $4{ }^{\circ} \mathrm{C}$. Cells were washed twice with PBS and incubated with antihuman $\mathrm{ABCB} 1$ monoclonal antibody (17F9, 1: 50 dilution in PBS) for $90 \mathrm{~min}$. $\mathrm{ABCB} 1$ was stained by incubation with fluorescein isothiocyanate-labeled goat anti-mouse antibody (1:50 dilution in PBS) for $90 \mathrm{~min}$. After washing, cells were mounted in glycerol-carbonate and examined on a Zeiss LSM510 confocal microscope (Heidelberg, Germany) using laser with incident beam at $488 \mathrm{~nm}$. As controls for nonspecific staining, the first antibody was omitted.

\subsection{0. $A B C B 1$ expression}

HepG2 cells $\left(5 \times 10^{6}\right)$ were washed with PBS and fixed in $3.7 \%(\mathrm{v} / \mathrm{v})$ formaldehyde solution for $15 \mathrm{~min}$ at room temperature. The cells were washed twice with PBS and then incubated with anti-human ABCB1 monoclonal antibody (17F9, 1: 50 dilution in PBS) for $60 \mathrm{~min}$ at $4{ }^{\circ} \mathrm{C}$. After incubation, the cells were washed twice with PBS and ABCB1 was stained by incubation with fluorescein isothiocyanate (FITC)-labeled goat anti-mouse antibody (1:50 dilution in PBS) for $60 \mathrm{~min}$ at $4{ }^{\circ} \mathrm{C}$. After incubation, the cells were resuspended in $300 \mu \mathrm{L}$ PBS for flow cytometric analysis.

\subsection{ABCB1 $m R N A$ expression by real-time $P C R$}

RNA was extracted from HepG2 cells and PBMCs $\left(5 \times 10^{6}\right.$ to $1 \times 10^{7}$ cells $)$ using TRIzol ${ }^{\circledR}$ Reagent. cDNA was produced from 2 or $1 \mu \mathrm{g}$ of total RNA by Revertaid ${ }^{\mathrm{TM}} \mathrm{M}-\mathrm{MuLV}$ Reverse Transcriptase and $A B C B 1 \mathrm{mRNA}$ was measured by TaqMan quantitative PCR assay, using glyceraldehyde-3-phosphate dehydrogenase (GAPD) as housekeeping gene.

The real-time PCR assays were carried out in 96-well plates using a 7500 Real-Time PCR system (Applied Biosystems, Foster City, CA, USA). The thermal cycler protocol consisted of 40 cycles of denaturation at $95{ }^{\circ} \mathrm{C}$ for $15 \mathrm{~s}$ and annealing/extension at $60{ }^{\circ} \mathrm{C}$ for $1 \mathrm{~min}$. The primers and probe sequences used for $\mathrm{ABCB} 1$ mRNA detection were as follows: $\mathrm{ABCB} 1$ forward $5^{\prime}$ GTCTGGACAAGCACTGAAAGATAAGA-3', ABCB1 reverse 5'CAACGGTTCGGAAGTTTTCTATTGC- $3^{\prime}$ and ABCB1 probe $5^{\prime}$-FAM CTGGGAAGATCGCTACTGAA-NFQ- ${ }^{\prime}$. The relative quantitation value of each target gene was analyzed using a comparative $C_{\mathrm{T}}$ method. The following formula was used to calculate the relative amount of the transcript in the sample and normalized to an endogenous reference (GAPD): $2^{-\Delta \Delta \mathrm{CT}}$, where $\Delta C_{\mathrm{T}}$ is the difference in $C_{\mathrm{T}}$ between the gene of interest and GAPD, and $\Delta \Delta C_{\mathrm{T}}$ for the sample =mean $\Delta C_{\mathrm{T}}$ of the sample - mean $\Delta C_{\mathrm{T}}$ of the control sample (used as calibrator). In the case of the patients, this formula was used to calculate the variation in $A B C B I$ mRNA levels after treatment with atorvastatin and to calculate the levels before and after treatment, we used the formula $2^{-\Delta C T}$.

\subsection{Rhodamine 123 efflux assay}

ABCB1 functional activity was determined by Rhodamine 123 (Rh123) efflux assay, adapted from the protocol described by Lee and Piquette [21]. Cell monolayers were prepared by plating $3 \times 10^{5}$ cells per well in 6 -well cell culture plates the day before use. After overnight incubation at $37^{\circ} \mathrm{C}$, cell monolayers were treated with atorvastatin $(0$ to $20 \mu \mathrm{M})$ for $24 \mathrm{~h}$. Control and atorvastatin treated cells were harvested by Trypsin-versene mixture and centrifuged at $400 \times g$ for $5 \mathrm{~min}$. The cells were washed once with ice cold PBS, then resuspended with $500 \mu \mathrm{L}$ PBS and pre-incubated with $0.5 \mu \mathrm{M}$ Rh123 for $15 \mathrm{~min}$. The cells were then incubated in the presence or absence of the ABCB1 inhibitor verapamil $(50 \mu \mathrm{M})$ and the efflux of Rh123 was measured for $60 \mathrm{~min}$. At 0 and 60 min incubation, cells were washed twice with ice cold PBS and the cell pellet was resuspended with $300 \mu \mathrm{L}$ PBS and immediately used for flow cytometric analysis of Rh123 retention. ABCB1 mediated efflux was determined using the following formulas.

$$
\% \text { Rh123 efflux }=\frac{[\mathrm{Rh} 123]^{0 \mathrm{~min}}-[\mathrm{Rh} 123]^{60 \min }}{[\mathrm{Rh} 123]^{0 \mathrm{~min}}}
$$

ABCB1-mediated efflux $=\%$ Rh123 efflux(absence of verapamil $)$

$$
-\% \text { Rh123 efflux(presence of verapamil) }
$$

\subsection{Flow cytometric analysis}

Cells (numbering 10,000) were analyzed in a FACSCalibur flow cytometer (Becton Dickinson, San Jose, CA, USA) using an argon-ion laser (15 mW) with incident beam at $488 \mathrm{~nm}$. Green (rhodamine 123 and FITC) and red (propidium iodide) fluorescences were collected through $530 \mathrm{~nm}$ and $585 \mathrm{~nm}$ filters, respectively. Data were acquired and analyzed using the FACS/Cell Quest software (Becton Dickinson, San Jose, CA) and results were expressed as mean of the fluorescence intensity.

\subsection{Statistical analysis}

Each set of experiments was repeated at least three times in cells pertaining to different passages. Results are reported as means \pm SEM. Differences between the means were analyzed by one-way analysis of variance (ANOVA) followed 
by the Tukey test or Mann-Whitney/Student's $t$-test and correlation analysis were performed by Pearson or Spearman rank correlation coefficient using Prism (Graph Pad Software, Inc., San Diego, CA, USA). Statistical significance was set for $p<0.05$.

\section{Results}

\subsection{Cell viability and DNA fragmentation}

Treatment of human hepatoma cells with $0-20 \mu \mathrm{M}$ atorvastatin for $24 \mathrm{~h}$ had no effect on viability or DNA fragmentation of HepG2 cells (data not shown). All cells had viability $\geq 97 \%$ and the percentage of cells with fragmented DNA was less than $7 \%$.

\subsection{P-gp 1 detection and expression}

Immunohistochemical analysis with 17F9 monoclonal antibody was used to detect ABCB1 in hepatocytes. This antibody specifically recognizes an external domain of $\mathrm{ABCB} 1$. As expected, $\mathrm{ABCB} 1$ was located at the apical membrane of the bile canaliculi in HepG2 (Fig. 1).

Significant expression of ABCB1 was found in HepG2 cells as compared to the negative control (absence of primary antibody). Atorvastatin increased the expression of ABCB1 as compared with vehicle control $(0 \mu \mathrm{M})$ mainly at high concentrations (10 and $20 \mu \mathrm{M})$ (Fig. 2).

\subsection{ABCB1 mRNA expression}

Semi-quantitative real-time PCR was used to detect $A B C B 1$ mRNA expression in HepG2 cells. Compared to the vehicle control, treatment with $1 \mu \mathrm{M}$ or higher doses of atorvastatin for $24 \mathrm{~h}$ resulted in an approximately $60 \%$ decrease in the $A B C B 1$ transcription levels. This reduction in mRNA levels was significant for $1(0.36 \pm 0.08) 10(0.47 \pm 0.09)$ and $20 \mu \mathrm{M}(0.37 \pm$ $0.06)$ compared to vehicle $(1.0 \pm 0.22, p<0.05)$; the values are presented as mean $\pm \mathrm{SEM}$ of 4 experiments (Fig. 3A). To examine whether this decrease in mRNA levels was due to an inhibition of the cholesterol de novo synthesis pathway, HepG2

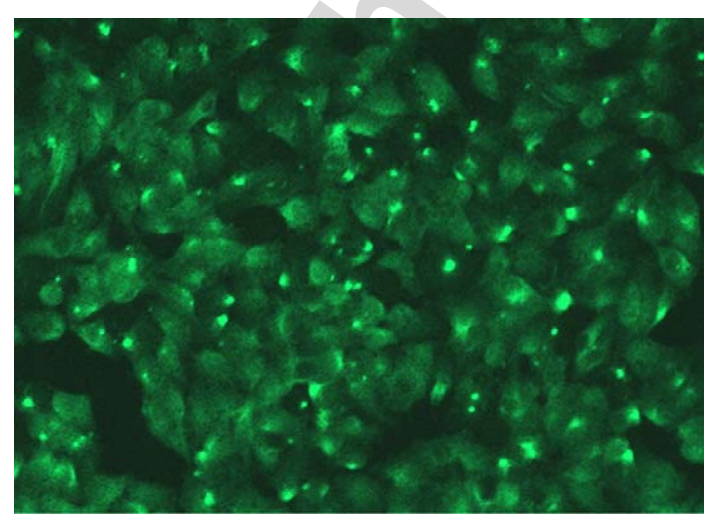

Fig. 1. Immunohistochemical detection of ABCB1 in HepG2 cells. Fluorescence corresponds to bile canaliculi in the contact cell regions. Cells were grown on glass cover slips and detected with 17F9 indirect immunofluorescence.

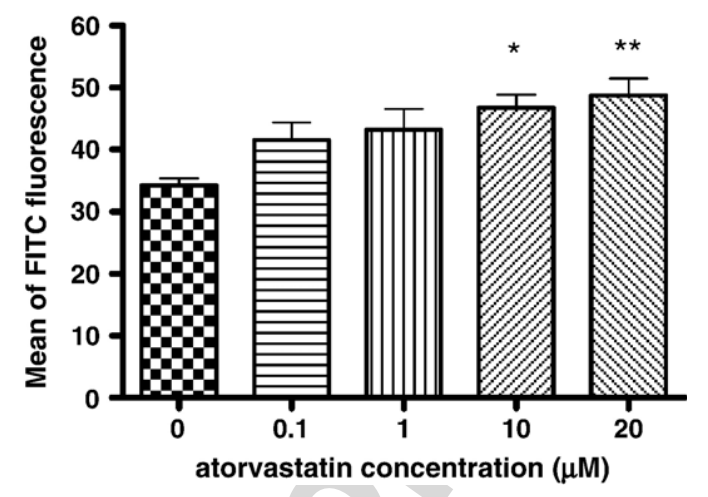

Fig. 2. Effect of atorvastatin treatment on ABCB1 expression in HepG2 cells. Cells were treated for $24 \mathrm{~h}$ with atorvastatin, and then FACS analysis were performed in HepG2 suspension cells using 17F9 indirect immunofluorescence. Data are reported as mean \pm SEM, $n=4$., ${ }^{*} p<0.05 ; * * p<0.01$ as compared to 0 $\mu \mathrm{M}$ atorvastatin as indicated by ANOVA and Tukey test.

cells were treated with $0.2 \mathrm{mM}$ of mevalonic acid lactone along with atorvastatin $20 \mu \mathrm{M}$. The addition of mevalonic acid lactone did not reverse the atorvastatin induced decrease in $A B C B 1$ transcript levels, suggesting that its effect is not modulated by any intermediate of the de novo cholesterol synthesis pathway (Fig. 3B).
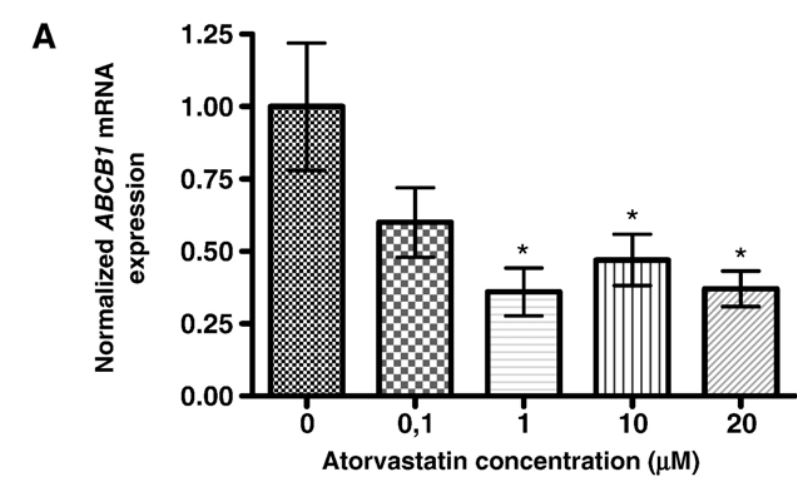

B

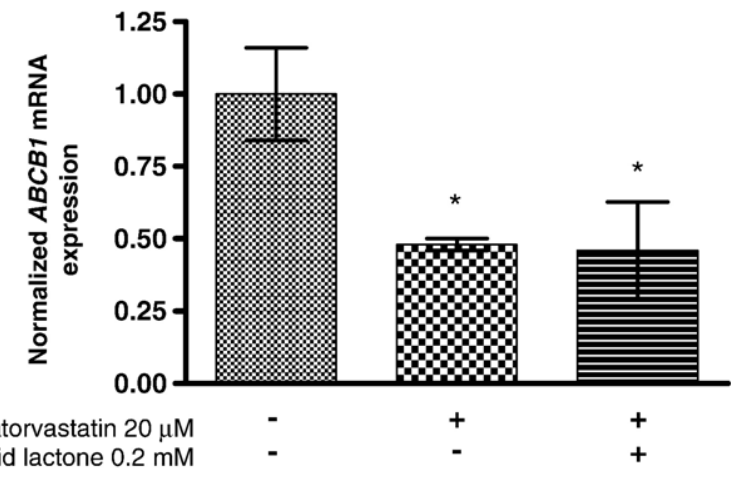

Fig. 3. Atorvastatin decreases $A B C B 1$ mRNA expression in HepG2 cells, which is not reversed by mevalonic acid lactone. (A) Real-time PCR was performed using total RNA extracted from $24 \mathrm{~h}$ atorvastatin-treated ( 0 to $20 \mu \mathrm{M})$ and vehicle control $(0 \mu \mathrm{M})$ cells. Values are reported as mean \pm SEM, $n=4$. ${ }^{*} p<0.05$ as compared to $0 \mu \mathrm{M}$ atorvastatin as indicated by ANOVA and Tukey test. (B) HepG2 cells were treated with atorvastatin $20 \mu \mathrm{M}$ in the presence or absence of mevalonic acid lactone $(0.2 \mathrm{mM})$ for $24 \mathrm{~h}$. Data are reported as mean $\pm \mathrm{SEM}$, $n=4$. ${ }^{*} p<0.05$ as compared to $0 \mu \mathrm{M}$ atorvastatin as indicated by ANOVA and Tukey test. 


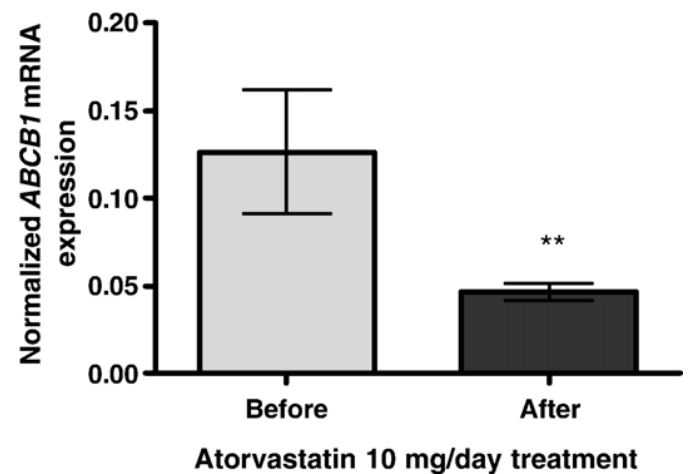

Fig. 4. $A B C B 1$ mRNA levels in hypercholesterolemic individuals before and after atorvastatin therapy $(10 \mathrm{mg} /$ day $)$. The individuals were treated with atorvastatin $10 \mathrm{mg} /$ day for 4 weeks and real-time PCR were performed using total RNA extracted from PBMCs isolated before and after treatment. Data are mean \pm SEM, $n=69$ individuals. ${ }^{*} p<0.05$ as compared to $0 \mu \mathrm{M}$ atorvastatin as indicated by Mann-Whitney $U$ test.

Evaluation of $A B C B 1$ transporter expression in PBMCs revealed that after an atorvastatin $10 \mathrm{mg}$ per day treatment the levels of ABCB1 transcript were reduced 63\% (Fig. 4). These findings are in agreement with the results found for HepG2 cells.

\subsection{Association of $m R N A$ expression of $A B C B 1$ transporter in PBMCs with C3435T polymorphism}

Relative allele frequencies (wild-type, variant) C3435T polymorphism was, 0.53 and 0.47 , respectively, and observed genotype distributions were consistent with the HardyWeinberg equilibrium. There was no association between the $A B C B 1 \mathrm{C} 3435 \mathrm{~T}$ polymorphism and the mRNA expression in PBMCs (Fig. 5). We also evaluated the genotype of C3435T polymorphism for HepG2 being characterized by $\mathrm{CC}$ genotype.

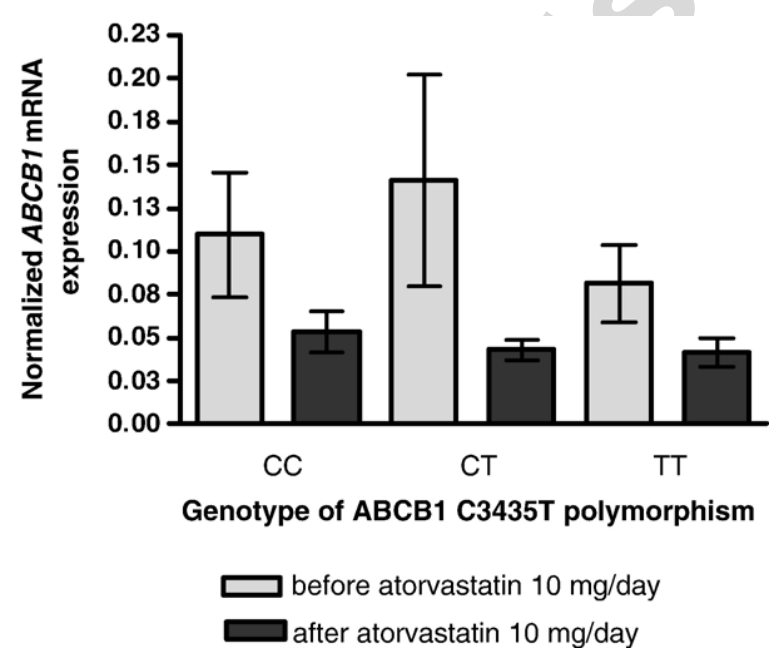

Fig. 5. $A B C B 1 \mathrm{mRNA}$ levels in hypercholesterolemic individuals according to C3435T genotype, before and after atorvastatin therapy (10 mg/day). Genomic DNA were extracted from blood samples and used to perform PCR-RFLP to detect C3435T polymorphism of $A B C B 1$ gene. Data are mean \pm SEM, $n=18$ for $3435 \mathrm{CC}, 37$ for 3435CT and 14 for 3435TT. $p>0.05$ compared to controls as indicated by ANOVA.

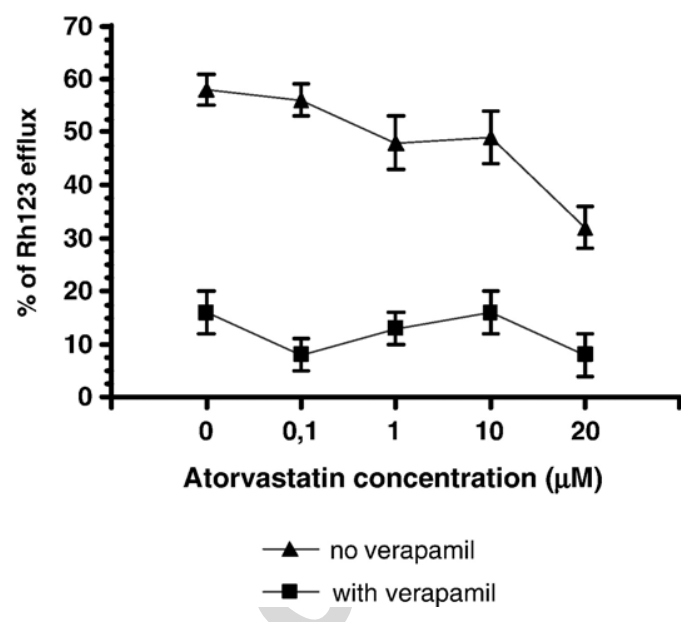

Fig. 6. The effect of atorvastatin treatment on Rhodamine 123 efflux in the presence/absence of verapamil $(50 \mu \mathrm{M})$ in HepG2 cells. Cells were treated with atorvastatin for $24 \mathrm{~h}$. Rhodamine 123 was added and cells were incubated for 60 $\min$ at $37^{\circ} \mathrm{C}$ in the presence or absence of verapamil. Data are the mean values \pm SEM of 6 experiments.

\subsection{ABCB1 efflux activity}

To examine the effect of atorvastatin on $\mathrm{ABCB} 1$ functional activity, HepG2 cells were treated with 0.1 to $20 \mu \mathrm{M}$ atorvastatin for $24 \mathrm{~h}$ and Rh123 efflux was measured in the presence or absence of the ABCB1 inhibitor verapamil $(50 \mu \mathrm{M})$. Rh123 efflux was decreased in HepG2 cells treated with atorvastatin, and in the presence of verapamil $(50 \mu \mathrm{M})$ the Rh123 efflux was alomst completely inhibited and was not influenced by the atorvastatin treatment (Fig. 6). Atorvastatin induced a concentration-dependent inhibition of the ABCB1-mediated efflux activity (inset, Fig. 7). Compared to vehicle, significant reduction of $\mathrm{ABCB} 1$-mediated efflux activity was observed in cells treated with $20 \mu \mathrm{M}$ atorvastatin (Fig. 7).

\subsection{Correlation analysis}

Analysis of $A B C B 1$ mRNA levels in patients treated with atorvastatin $10 \mathrm{mg}$ per day, revealed a significant correlation between the amount of $A B C B 1 \mathrm{mRNA}$ and the percentage of reduction or increase of total cholesterol (TC) and creatine kinase (CK), respectively (TC: $r=-0.31, p=0.010$; $\mathrm{CK}$ : $r=0.30, p=0.014$ ) (Figs. 8, 9).

\section{Discussion}

Membrane transporters like the ABC-transporter ABCB1 may substantially impact the pharmacokinetic properties of many drugs and endogenous substrates. Hence, optimum doses of ABC-transporter substrates may vary greatly between patients and dose adjustment may be required even in the same a patient to maintain effectiveness and avoid toxicity. Here we present the first evidence that atorvastatin modulates the activity of the ABCB 1 transporter in a human hepatoma cell line 


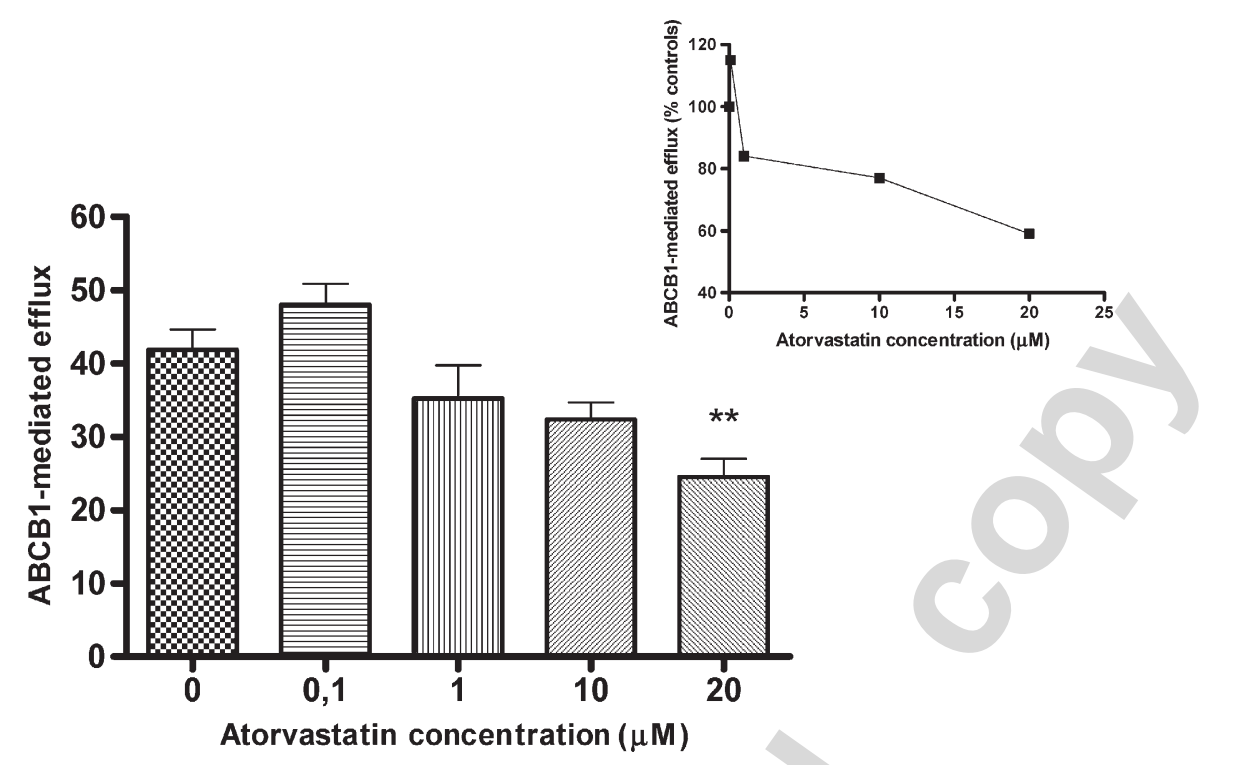

Fig. 7. Effect of atorvastatin treatment on ABCB1 efflux activity in HepG2 cells. ABCB1- mediated efflux of Rh123 was measured in 24 h atorvastatin-treated (0$20 \mu \mathrm{M})$ and vehicle control $(0 \mu \mathrm{M})$ cells. Values are reported as mean \pm SEM of 6 experiments. $* * p<0.01$ as compared to $0 \mu \mathrm{M}$ atorvastatin as indicated by ANOVA and Tukey test. Inset: ABCB1-mediated efflux reported as percentage of controls.

and in PBMCs of individuals treated with atorvastatin $10 \mathrm{mg}$ once daily for 4 weeks.

In addition to the in vivo experiments, HepG2 cells were cultured in the presence of various concentrations of atorvastatin found in the blood levels after an oral dose of 10 to $80 \mathrm{mg}$ per day [22]. Even a high dose of atorvastatin did not cause any significant toxic effect on HepG2 cells.

Atorvastatin induced a concentration-dependent inhibition of the ABCB1 efflux activity in HepG2 cells. Other studies have shown that statins are inhibitors of ABCB1 activity in different cell lines [23-26]. However, the reduction in ABCB1 activity $(41 \%, \mathrm{IC} 50=5.4 \pm 0.6 \mu \mathrm{M})$ induced by the maximum dose of $20 \mu \mathrm{M}$ atorvastatin in HepG2 cells was higher than that found in other cell types, such as murine monocytic leukemia cell line P388/MDR (IC50=30.1 $12.1 \mu \mathrm{M}$ ) [23], Chinese hamster ovary cells overexpressing ABCB1 (IC50= $356 \pm 25 \mu \mathrm{M})$, and fibroblasts transfected with human ABCB1 $(\mathrm{IC} 50=307 \pm 14 \mu \mathrm{M})$ [24] and Madin-Darby canine kidney (MDCK) cells $(\mathrm{IC} 50>100 \mu \mathrm{M})$ [25]. This discrepancy in the

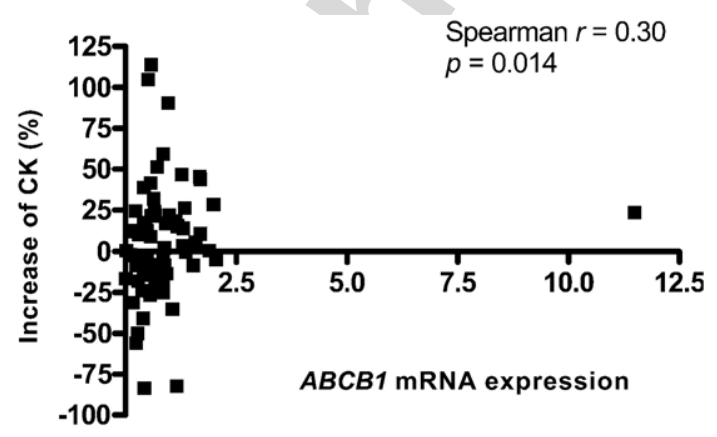

Fig. 8. Correlation analysis between $A B C B 1$ mRNA levels and percentage of increase of creatine kinase in hypercholesterolemic individuals after atorvastatin therapy (10 mg/day). Significant correlation between $A B C B 1 \mathrm{mRNA}$ in PBMCs and increase of serum creatine kinase (CK), $n=68, p=0.014$ as indicated by Spearman rank correlation coefficient. findings maybe due to differences in the method of measuring Rh123 fluorescence and, mainly, in the type of cell line used in the studies.

The influence of atorvastatin on $\mathrm{ABCB} 1$ expression was examined in HepG2 cells. As far as we know, this is the first evidence that $\mathrm{ABCB} 1$ is regulated by atorvastatin in human cells. The increase of ABCB1 levels in HepG2 cells following exposure to high concentrations of atorvastatin for $24 \mathrm{~h}$ was similar to that found in the liver of rats continuously exposed to pravastatin or simvastatin (5 days, diet supplemented with $0.1 \% \mathrm{wt} / \mathrm{wt}$ ) [27]. However, analysis of the $A B C B 1 \mathrm{mRNA}$ expression in HepG2 cells showed a significant downregulation by atorvastatin. This reduction of mRNA levels was in agreement to the decreased ABCB1 activity. Similar observations were obtained in 69 patients with primary hypercholesterolemia treated with $10 \mathrm{mg}$ per day atorvastatin.

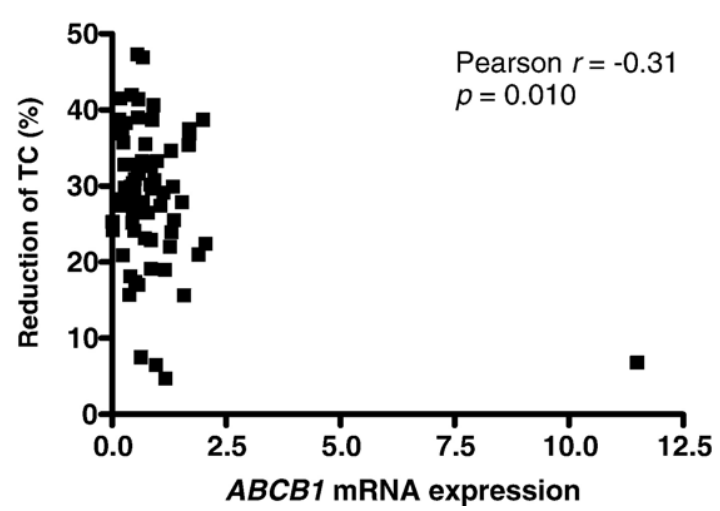

Fig. 9. Correlation analysis between $A B C B 1 \mathrm{mRNA}$ levels and percentage of reduction of total cholesterol in hypercholesterolemic individuals after atorvastatin therapy $(10 \mathrm{mg} /$ day). Significant correlation between $A B C B 1 \mathrm{mRNA}$ in PBMCs and reduction of serum total cholesterol (TC), $n=69, p=0.010$ as indicated by Pearson correlation coefficient. 
Expression of $A B C B 1$ mRNA was $63 \%$ decreased in humans treated with atorvastatin.

The possible involvement of intermediates of the de novo cholesterol synthesis pathway on atorvastatin induced decrease of $A B C B 1$ mRNA expression was investigated. The induced decrease in $A B C B 1$ transcript was not reverted by the addition of mevalonic acid lactone, suggesting that its effect is not modulated by any intermediate of the de novo cholesterol synthesis pathway.

Treatment with verapamil $(15-30 \mu \mathrm{M})$, a specific ABCB1 inhibitor, down-regulated $A B C B 1$ gene expression caused by decreased $A B C B 1$ proximal promoter activity [28].

In addition to a decreased transcriptional rate, reduced $A B C B 1$ mRNA levels could also result from post-transcriptional mechanisms, for example mRNA stability. Muller et al. [28] found that $A B C B 1$ mRNA is stable and $A B C B 1$ mRNA degradation remains unchanged in the verapamil-treated versus control cells. A cis-acting polymorphism, 3435C $>\mathrm{T}$, in the $A B C B 1$ gene was associated with lower mRNA levels in the liver, caused by reduced mRNA stability [29]. Polymorphisms may play a major role in mRNA degradation by changing mRNA secondary structure. After genotyping HepG2, it was characterized as being $\mathrm{CC}$ for $A B C B 1 \mathrm{C} 3435 \mathrm{~T}$ polymorphism.

We then investigated the effect of $A B C B 1 \mathrm{C} 3435 \mathrm{~T}$ polymorphism on ABCB1 expression in PBMCs of 69 individuals. No significant association between this polymorphism and $A B C B 1$ mRNA expression was found. Studies with human peripheral blood lymphocytes that also tried to found an association between ABCB1 polymorphisms and $\mathrm{ABCB} 1$ expression [30,31] or function [32] failed to found a possible role of polymorphism in $\mathrm{ABCB} 1$ expression and function.

This lack of association between $\mathrm{C} 3435 \mathrm{~T}$ polymorphism and mRNA levels may be due to the differences in $A B C B 1 \mathrm{mRNA}$ expression in the liver and PBMCs, which is believed to be 10 times smaller than in liver [31].

$A B C B 1$ expression may be also regulated by the pregnane $\mathrm{X}$ receptor (PXR) a ligand-activated transcription factor that is well known to mediate induction of CY3A4 gene transcription by xenobiotics [33]. Atorvastatin is capable of activating human PXR and increases the amounts of CYP3A4 mRNA and protein [34]. ABCB1 and CYP3A are likely to be complementary systems to detoxify hydrophobic and potentially toxic compounds. Decreased $A B C B 1$ levels result in increased CYP expression; on the other hand, under conditions of suppressed CYP expression (e.g., under cytokine-induced stress), $A b c b 1 b$ expression was found to be increased [35]. Preliminary experiments indicate that $C P 3 A 4 \mathrm{mRNA}$ expression increased in HepG2 cells treated with atorvastatin 1-20 $\mu \mathrm{M}$ (data not shown).

In patients treated with atorvastatin $10 \mathrm{mg}$ per day, a positive correlation between $A B C B 1$ mRNA levels and percentage of increase of creatine kinase $(\mathrm{CK})$ activity was found. As a result reduced levels of $A B C B 1$ may protect the patients against adverse effects as the occurrence of myopathy. Conversely, we found a negative correlation between total cholesterol reductions and $\mathrm{ABCB} 1 \mathrm{mRNA}$ levels after atorvastatin treatment.
Thus, decreased levels of $A B C B 1$ may result in a more effective response to atorvastatin.

We found an unexpected increase in ABCB1 protein levels in HepG2 cells treated with atorvastatin. Taking into consideration the decrease in mRNA levels and on ABCB1 activity, the antibody probably recognized the peptide resulted from the ABCB1 proteolysis. Stability of ABCB1 is regulated by ubiquitination, which is mediated through proteasomal pathway [36]. Zhang et al. [36] have shown that enhanced ubiquitination of $\mathrm{ABCB} 1$ results in a decrease of the function of the transporter, as shown by increased ABCB1 intracellular accumulation and degradation. Another possibility is that atorvastatin disrupted of ABCB1 ubiquitination within $24 \mathrm{~h}$, contributing to its accumulation in HepG2 cells. This effect can also explain the increase in ABCB1 levels found in canalicular membrane of hepatocytes after a 24-h treatment with atorvastatin.

Fujita et al. [37] reported that proteasome inhibitors sensitize the multidrug resistant MCF7/ADR cells through suppression of the $A B C B 1$ gene decreasing the $\mathrm{ABCB} 1$ levels. If atorvastatin really causes a disruption of ubiquitin-proteasome pathway, there is a reduction in $A B C B 1$ mRNA levels.

In conclusion, the results presented herein suggest that atorvastatin treatment inhibits $\mathrm{ABCB} 1$ synthesis in PBMCs and hepatocytes and decreases $\mathrm{ABCB} 1$ activity in HepG2 cells. ABCB1 plays an important role in cell protection as well as in drug secretion and/or disposition. Therefore, inhibition of $\mathrm{ABCB} 1$ synthesis may increase the atorvastatin efficacy, leading to a more pronounced reduction of plasma cholesterol.

\section{Acknowledgments}

This work is supported by grants from FAPESP (03/020868) and CNPQ (473694/03-4). A. C. Rodrigues is a recipient of fellowship from FAPESP (2004/01693-0; 2005/60240-9). The authors are grateful to Adilson da Silva Alves, José Roberto Mendonça, Geraldina de Souza, Érica Paula Portiolli, Maria Alice V. Willrich, Fabiana Gengivir and Simone S. Arazi for the excellent technical support.

\section{References}

[1] H. Lennernäs, Clinical pharmacokinetics of atorvastatin, Clin. Pharmacokinet. 42 (2003) 1141-1160.

[2] S. Bellosta, N. Ferri, F. Bernini, R. Paoletti, A. Corsini, Non-lipid-related effects of statins, Ann. Med. 32 (2000) 164-176.

[3] J.M. Mallinowski, Atorvastatin: a hydroximethylglutaryl-coenzyme A reductase inhibitor, Am. J. Syst. Pharm. 55 (1998) 22253-22267.

[4] M.M. Hoffmann, B.R. Winkelmann, H. Wieland, W. März, The significance of genetic polymorphisms in modulating the response to lipid-lowering drugs, Pharmacogenomis 2 (2001) 1-15.

[5] J.M. McKenney, Pharmacologic options for aggressive low-density lipoprotein cholesterol lowering: benefits versus risks, Am. J. Cardiol. 96 (2005) 60

[6] R.H. Ho, R.B. Kim, Transporters and drug therapy: implications for drug disposition and disease, Clin. Pharmacol. Ther. 78 (2005) 260-277.

[7] C.G. Dietrich, A. Geier, R.P.J. Oude Elferink, ABC of oral bioavailability: transporters as gatekeepers in the gut, Gut 52 (2003) 1788-1795. 
[8] R.A. Boyd, R.H. Stern, B.H. Stewart, X. Wu, E.L. Reyner, E.A. Zegarac, E.J. Randinitis, Atorvastatin coadministration may increase digoxin concentrations by inhibition of intestinal P-glycoprotein-mediated secretion, J. Clin. Pharmacol. 40 (2000) 91-98.

[9] X. Wu, L.R. Whitfield, B.H. Steart, Atorvastatin transport in the Caco-2 cell model: contributions of P-glycoprotein and the proton-monocarboxylic acid co-transporter, Pharm. Res. 17 (2000) 209-215.

[10] S. Hoffmeyer, O. Burk, O. von Richter, H.P. Arnold, J. Brockmöller, A. Johne, et al., Functional polymorphisms of the human multidrugresistance gene: multiple sequence variations and correlation of one allele with P-glycoprotein expression and activity in vivo, Proc. Natl. Acad. Sci. U. S. A. 97 (2000) 3473-3478.

[11] R.B. Kim, B.F. Leake, E.F. Choo, G.K. Dresser, S.V. Kubba, U.I. Schwarz, A. Taylor, H.G. Xie, J. McKinsey, S. Zhou, L.B. Lan, J.D. Schuetz, E.G. Schuetz, G.R. Wilkinson, Identification of functionally variant MDRI alleles among European Americans and African Americans, Clin. Pharmacol. Ther. 70 (2001) 189-199.

[12] N. von Ahsen, M. Richter, C. Grupp, B. Ringe, M. Oellerich, V.W. Armstrong, No influence of the $M D R-1 \mathrm{C} 3435 \mathrm{~T}$ polymorphism or a CYP3A4 promoter polymorphism (CYP3A4-V allele) on dose-adjusted cyclosporin A trough concentrations or rejection incidence in stable renal transplant recipients, Clin. Chem. 47 (2001) 1048-1052.

[13] U. Brinkmann, I. Roots, M. Eichelbaum, Pharmacogenetics of the human drug-transporter gene $M D R 1$ : impact of polymorphisms on pharmacotherapy, Drug Discov. Today 6 (2001) 835-839.

[14] Y. Kurata, I. Ieiri, M. Kimura, T. Morita, S. Irie, A. Urae, et al., Role of human $M D R 1$ gene polymorphism in bioavailability and interaction of digoxin, a substrate of P-glycoprotein, Clin. Pharmacol. Ther. 72 (2002) 209-219.

[15] K. Kajinami, M.E. Brousseau, J.M. Ordovas, E.J. Shaefer, Polymorphisms in the multidrug resistance-1 (MDRl) gene influence the response to atorvastatin treatment in a gender-specific manner, Am. J. Cardiol. 93 (2004) 1046-1050.

[16] J. Fellay, C. Marzolini, E.R. Meaden, Response to antiretroviral treatment in IIIV-I-infected individuals with allelic variants of the multidrug resistance transporter I a pharmacogenetic study, Lancet 3359 (2002) 30-36.

[17] D. Anglicheau, C. Verstuyft, P. Laurent-Puig, L. Becquemont, M.H. Schlageter, B. Cassinat, P. Beaune, C. Legendre, E. Thervet, Association of the multidrug resistance-1 gene single-nucleotide polymorphisms with the tacrolimus dose requirements in renal transplant recipients, J. Am. Soc. Nephrol. 14 (2003) 1889-1896.

[18] A.C. Rodrigues, I.M.M. Rebecchi, M.C. Bertolami, M.H. Hirata, R.D.C. Hirata, High baseline serum total and LDL cholesterol levels are associated with MDRl haplotypes in Brazilian hypercholesterolemic individuals of European descent, Braz. J. Med. Biol. Res. 38 (2005) 1389-1397.

[19] A. Boyum, Isolation of leucocytes from human blood. Further observations. Methylcellulose, dextran, and ficoll as erythrocyteaggregating agents, Scand. J. Clin. Lab. Invest. 97 (1968) 31-50.

[20] I. Nicoletti, G. Migliorati, M.C. Pagliacci, F. Grignani, C. Riccardi, A rapid and simple method for measuring thymocyte apoptosis by propidium iodide staining and flow cytometry, J. Immunol. Methods 139 (1991) 271-279.

[21] G. Lee, M. Piquette-Miller, Influence of IL-6 on MDR and MRP-mediated multidrug resistance in human hepatoma cells, Can. J. Physiol. Pharmacol. 79 (2001) 876-884.

[22] A. Mohammadi, J. Macri, R. Newton, T. Romain, D. Dulay, K. Adeli, Effects of atorvastatin on the intracellular stability and secretion of apolipoprotein B in HepG2 cells, Arterioscler. Thromb. Vasc. Biol. 18 (1998) 783-793
[23] K. Bogman, A.K. Peyer, M. Török, E. Küsters, J. Drewe, HMG-CoA reductase inhibitors and P-glycoprotein modulation, Br. J. Pharmacol. 132 (2001) 1183-1192.

[24] E.-J. Wang, C.N. Casciano, R.P. Clement, W. Johnson, HMG-CoA reductase inhibitors (statins) characterized as direct inhibitors of P-glycoprotein, Pharm. Res. 18 (2001) 800-806.

[25] J.H. Hochman, N. Pudvah, J. Qiu, M. Yamazi, C. Tang, J.H. Lin, T. Prueksaritanont, Interactions of human P-glycoprotein with simvastatin, simvastatin acid, and atorvastatin, Pharm. Res. 21 (2004) 1686-1691.

[26] C. Chen, R.J. Mireles, S.D. Campbell, J. Lin, J.B. Mills, J.J. Xu, T.A. Smolarek, Differential interaction of 3-hydroxy-3-methylglutaryl-CoA reductase inhibitors with $\mathrm{ABCB} 1, \mathrm{ABCC} 2$, and OATP1B1, Drug Metab. Dispos. 33 (2005) 537-545.

[27] G.J.E.J. Hooiveld, T.A. Vos, G.L. Scheffer, H. Van Goor, H. Koning, V. Bloks, A.E. Loot, D.K.F.R. Meijer, P.L.M. Jansen, F. Kuipers, M. Muller, 3-Hydroxy-3-methylglutaryl-Coenzyme A reductase inhibitors (statins) induce hepatic expression of the phospholipid translocase mdr2 in rats, Gastroenterology 117 (1999) 678-687.

[28] C. Muller, F. Gobin, E. Ferrandis, I. Cornil-Scharwtz, J.D. Bailly, C. Bordier, J. Bérnard, B.I. Sikic, G. Laurent, Evidence for transcriptional control of human $m d r l$ gene expression by verapamil in multidrugresistant leukemic cells, Mol. Pharmacol. 47 (1995) 51-56.

[29] D. Wang, A.D. Johnson, A.C. Papp, D.L. Kroetz, W. Sadee, Multidrug resistance polypeptide 1 (MDR1, ABCB1) variant 3435C(T affects mRNA stability, Pharmacogenet. Genomics 15 (2005) 693-704.

[30] K. Oselin, I. Nowakowksi-Gashaw, P.M. Mrozikiewicz, D. Wolbergs, R. Pahla, I. Roots, Quantitative determination of MDR1 mRNA expression in peripheral blood lymphocytes: a possible role of genetic polymorphism in the MDR1 gene, Eur. J. Clin. Invest. 33 (2003) 261-267.

[31] N. Alberman, F.H. Schmitz-Winnenthal, K. Z'graggen, C. Volk, M.M. Hoffman, W.E. Haefeli, J. Weiss, Expression of the drug transporters MDR1/ABCB1, MRP1/ABCC1, MRP2/ABCC2, BCRP/ABCG2, and $\mathrm{PXR}$ in peripheral blood mononuclear cells and their relationship with the expression in intestine and liver, Biochem. Pharmacol. 70 (2005) 949-958.

[32] K. Oselin, T. Gerloff, P.M. Mrozikiewicz, R. Pahka, I. Roots, MDR1 polymorphism G2677T in exon 21 and C3435T in exon 26 fail to affect rhodamine 123 efflux in peripheral blood lymphocytes, Fundam. Clin. Pharmacol. 17 (2003) 463-469.

[33] A.S. Kliewer, The nuclear pregnane $\mathrm{X}$ receptor regulates xenobiotic detoxification, J. Nutr. 133 (2003) 2444S-2447S.

[34] T.A. Kocarek, M.S. Dahn, H. Cai, S.C. Strom, N.A. Mercer-Haines, Regulation of CYP2B6 and CYP3A expression by hydroxymethylglutaryl coenzyme A inhibitors in primary cultured human hepatocytes, Drug Metab. Dispos. 30 (2002) 1400-1405.

[35] T.A. Vos, G.J.E.J. Hooiveld, H. Koning, S. Childs, D.K. Meijer, H. Moshage, P.L. Jansen, M. Muller, Up-regulation of the multidrug resistance genes, Mrp1 and Mdr1b, and down-regulation of the organic anion transporter, Mrp2, and the bile salt transporter, Spgp, in endotoxemic rat liver, Hepatology 28 (1998) 1637-1644.

[36] Z. Zhang, J.-J. Wu, W.N. Hait, J.-M. Yang, Regulation of the stability of P-glycoprotein by ubiquitination, Mol. Pharmacol. 65 (2004) 395-403.

[37] T. Fujita, K. Washio, D. Takabatake, H. Takahashi, S. Yoshitomi, K. Tsukuda, Y. Ishibe, Y. Ogasawara, H. Doihara, N. Shimizu, Proteasome inhibitors can alter the signaling pathways and attenuate the P-glycoprotein-mediated multidrug resistance, Int. J. Cancer 117 (2005) 670-682. 